\title{
Diagnosis and Treatment of Neuroleptic Malignant Syndrome in the Intensive Care Unit: A Case Report
}

\author{
Diagnóstico e Tratamento de Síndrome Maligno dos \\ Neurolépticos em Unidade de Cuidados Intensivos: \\ Relato de um Caso Clínico
}

Ana MAIA ${ }^{1,2,3}$, Gonçalo COTOVIO ${ }^{1,2,3}$, Bernardo BARAHONA-CORRÊA ${ }^{1,2,3}$, Albino J. OLIVEIRA-MAIA $\rrbracket^{1,2,3}$

Acta Med Port 2021 Jun;34(6):464-467 • https://doi.org/10.20344/amp.13019

ABSTRACT

Neuroleptic malignant syndrome is a neurological emergency caused by dysregulation of dopaminergic neurotransmission. While it is typically characterized by muscle rigidity, fever and altered mental status, it may have a heterogeneous and non-specific presentation, leading to delays in diagnosis and treatment. Treatment involves cessation of dopamine-receptor antagonists and supportive measures, but in more severe cases, bromocriptine, dantrolene, benzodiazepines and/or electroconvulsive therapy should be considered. We present the case of a 66-year-old man with severe neuroleptic malignant syndrome, diagnosed due to need for continuous invasive ventilation in an Intensive Care Unit, after successful treatment for respiratory sepsis. The patient recovered after electroconvulsive therapy and administration of bromocriptine. This unusually severe case illustrates the need for a high level of suspicion for neuroleptic malignant syndrome in critically ill patients with malignant catatonic syndromes, allowing for an early diagnosis and potentially lifesaving treatment.

Keywords: Intensive Care Units; Neuroleptic Malignant Syndrome/diagnosis; Neuroleptic Malignant Syndrome/therapy

\section{RESUMO}

A síndrome maligna dos neurolépticos é uma emergência neurológica causada pela desregulação da neurotransmissão dopaminérgica. Apesar de habitualmente caracterizada por rigidez muscular, febre e alteração do estado mental, pode apresentar-se de forma inespecífica e heterogénea, atrasando o diagnóstico e tratamento. O tratamento engloba a interrupção de antagonistas dos receptores dopaminérgicos, medidas de suporte e, em casos mais graves, bromocriptina, dantroleno, benzodiazepinas e/ou terapia electroconvulsiva. Neste artigo descrevemos o caso clínico de um homem de 66 anos com síndrome maligna dos neurolépticos grave, diagnosticada devido à necessidade de ventilação artificial continuada na Unidade de Cuidados Intensivos, após tratamento de uma sépsis respiratória. O doente melhorou significativamente após terapia electroconvulsiva e administração de bromocriptina. Este caso, de gravidade particular, sublinha a necessidade de manter um elevado nível de suspeita de síndrome maligna dos neurolépticos em doentes em estado crítico com síndromes catatónicos malignos, permitindo assim um diagnóstico precoce e tratamento dirigido.

Palavras-chave: Síndrome Maligna dos Neurolépticos/diagnóstico; Síndrome Maligna dos Neurolépticos/tratamento; Unidades de Cuidados Intensivos

\section{INTRODUCTION}

Neuroleptic malignant syndrome (NMS) is a neurological emergency caused by marked dysregulation of dopaminergic neurotransmission, usually following the administration of dopamine-receptor antagonists or sudden withdrawal of dopamine-receptor agonists. ${ }^{1}$ While it is typically characterized by rigidity, fever and altered mental status, ${ }^{2}$ NMS may have a heterogeneous and non-specific presentation, requiring cautious exclusion of other medical conditions. ${ }^{1}$ Consequently, diagnosis is frequently masked and delayed, contributing to the high mortality rate associated with this condition (currently around $14 \%$ ). ${ }^{2}$ Treatment includes discontinuation of dopamine-receptor antagonists, supportive measures and, in more severe cases, administration of bromocriptine, ${ }^{3}$ benzodiazepines, dantrolene ${ }^{4}$ and/or electroconvulsive therapy (ECT). ${ }^{5}$ We present the case of a 66-year-old man with unusually severe NMS, diagnosed due to the need for continuous invasive ventreatment of respiratory sepsis, and who recovered after a course of ECT and treatment with bromocriptine.

\section{CASE REPORT}

A 66-year-old man with prior diagnosis of schizophrenia was admitted to an ICU due to respiratory infection and septic shock syndrome, evolving rapidly to stupor and respiratory failure, and requiring sustained sedation for orotracheal intubation. At admission, all psychiatric medication was discontinued, and a course of empirical antibiotic treatment was started. Three days later, upon improvement of respiratory function and laboratory parameters, propofol was interrupted and the patient was extubated. However, leukocytosis and mild elevations of lactate dehydrogenase and liver transaminases persisted, despite normal creatine kinase levels. In the following days, generalized tremor and marked rigidity was tilation in an Intensive Care unit (ICU) after successful noted, and the patient developed sustained autonomic

1. Departament of Psychiatry and Mental Health. Hospital Egas Moniz. Centro Hospitalar de Lisboa Ocidental. Lisboa. Portugal.

2. NOVA Medical School | Faculdade de Ciências Médicas. Universidade NOVA de Lisboa. Lisboa. Portugal.

3. Champalimaud Research and Clinical Centre. Champalimaud Centre for the Unknown. Lisboa. Portugal.

$\triangle$ Autor correspondente: Albino J. Oliveira-Maia. albino.maia@neuro.fchampalimaud.org

Recebido: 27 de outubro de 2019 - Aceite: 03 de abril de 2020 - First published: 30 de setembro de 2020 - Online issue published: 01 de junho de 2021

Copyright @ Ordem dos Médicos 2021 
nervous dysfunction, with tachycardia (up to $117 \mathrm{bpm}$ ), unstable blood pressure (systolic: 130 - $163 \mathrm{mmHg}$; diastolic: 67 - $82 \mathrm{mmHg}$ ), diaphoresis, fever (up to $38.6^{\circ} \mathrm{C}$ ) and diarrhea. Rapid deterioration of respiratory function with accumulation of respiratory secretions and ineffective cough reflex led to re-intubation and prompted a new course of empirical antibiotic treatment. Despite full resolution of the respiratory infection, motor and autonomic abnormalities persisted and weaning of invasive ventilation proved impossible, prompting a liaison consultation with both Neurology and Psychiatry.

Psychiatric assessment, review of medical records and family interview revealed that he had been diagnosed with schizophrenia at the age of 40 but had never complied with treatment. However, five months prior to the current episode, the patient had been admitted to a psychiatric inpatient unit and had started, for the first time, continued treatment with haloperidol (15 mg/day), clozapine (100 mg/ day) and flurazepam (15 mg/day). Except for childhood epilepsy, with no known manifestations or treatment since adolescence, medical history was unremarkable, as was family neuropsychiatric history. On examination, the patient was mostly uncooperative, responding only occasionally with yes-no answers using eye-blinks or finger movements. Waxy flexibility and catatonic posturing were noted (Video 1). Brain computed tomography (CT) and magnetic resonance imaging (MRI), electroencephalogram (EEG), cerebral-spinal fluid examination and cultures were unremarkable, and catatonia due to a medical condition, or NMS, were considered. Formal assessment revealed a Bush-Francis Catatonia Rating Scale (BFCRS) score of 23, making it impossible to perform other clinical assessments, including the Montreal Cognitive Assessment Scale (MoCA).

Since all neuroleptics had been interrupted previously, and supportive measures were fully in place, treatment was started with lorazepam (2.5 to $5 \mathrm{mg} /$ day), with no clear benefit. At this moment, ECT was offered and accepted by the patient and family. A course of twice weekly, bitemporal, brief-pulse ECT was thus started on day 26 after admission, under propofol (50 to $120 \mathrm{mg} / \mathrm{session}$ ) and succinylcholine (50 to $75 \mathrm{mg} / \mathrm{session}$ ). After four sessions, the patient had improved sufficiently to be extubated (Video 2), and after

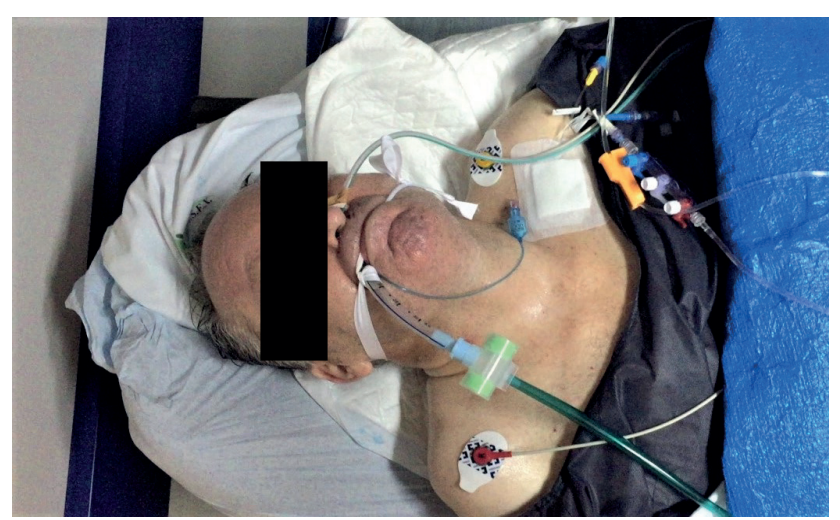

Figure 1 - Patient in the Intensive Care Unit (see Video 1: https:// www.actamedicaportuguesa.com/revista/index.php/amp/article/ view/13029/Video_01.mp4)

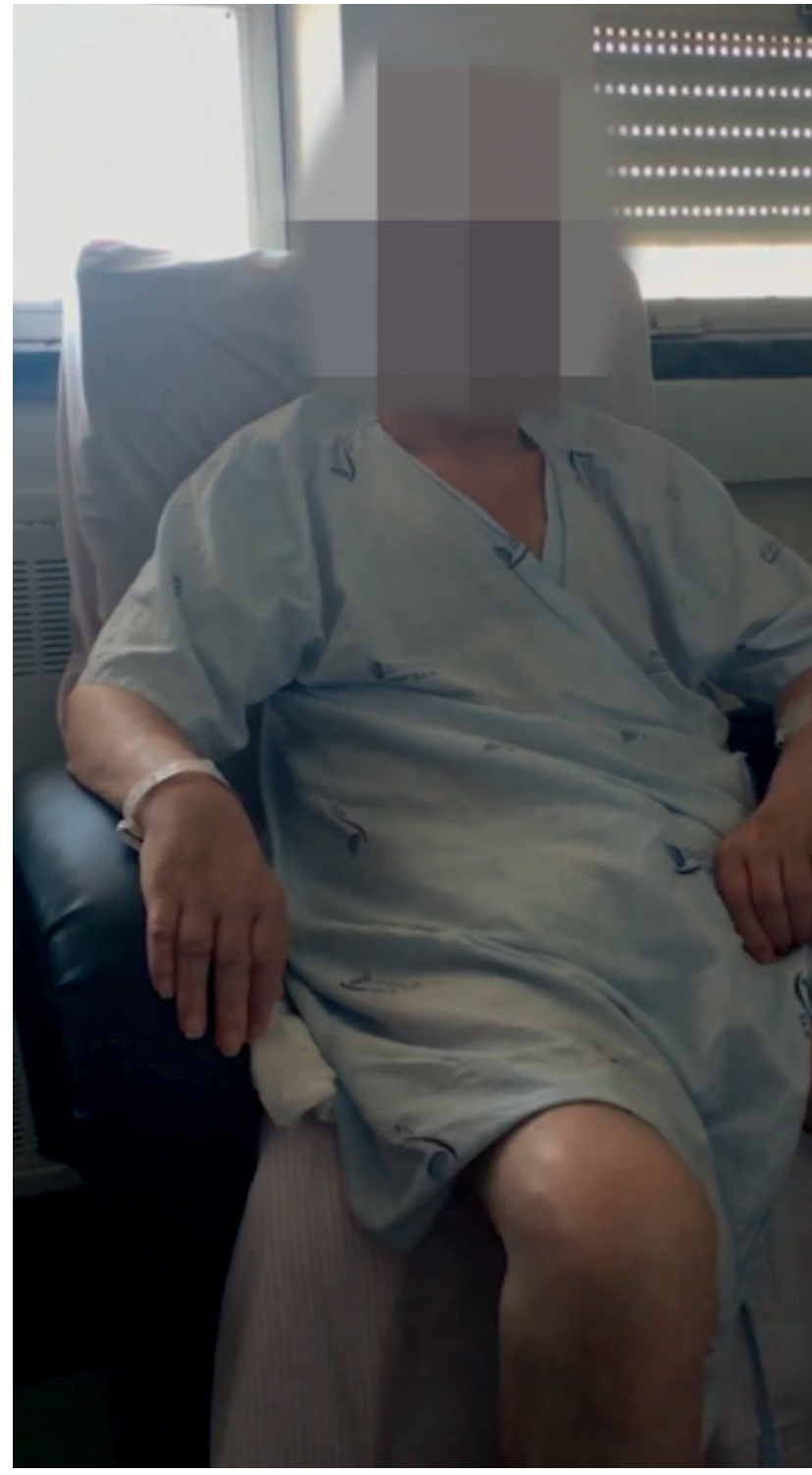

Figure 2 - Patient after completion of ECT and bromocriptine (see Video 2: https://www.actamedicaportuguesa.com/revista/index. php/amp/article/view/13029/Video_02.mp4)

11 treatments, given the stability of clinical response, with a $65,2 \%$ reduction in the BFRCS (score $=8$ ), ECT was interrupted. Bromocriptine was then started and titrated to 15 $\mathrm{mg} /$ day, resulting in further improvement, with most catatonic symptoms subsiding (BFCRS score $=1$ ) and a MoCA score of 11 (Video 3).

\section{DISCUSSION}

NMS is a life-threatening condition with a challenging diagnosis and treatment. Decreased dopamine D2 receptor activity within the nigrostriatal, hypothalamic and mesolimbic/cortical pathways has been proposed to explain the clinical triad that typically characterizes this syndrome, namely, rigidity, fever and altered mental status. ${ }^{6,7}$ However, patients may also present with minor manifestations, namely tachycardia, abnormal arterial pressure, tachypnea, diaphoresis and leukocytosis. ${ }^{8}$ Differential diagnosis is particularly dif- 

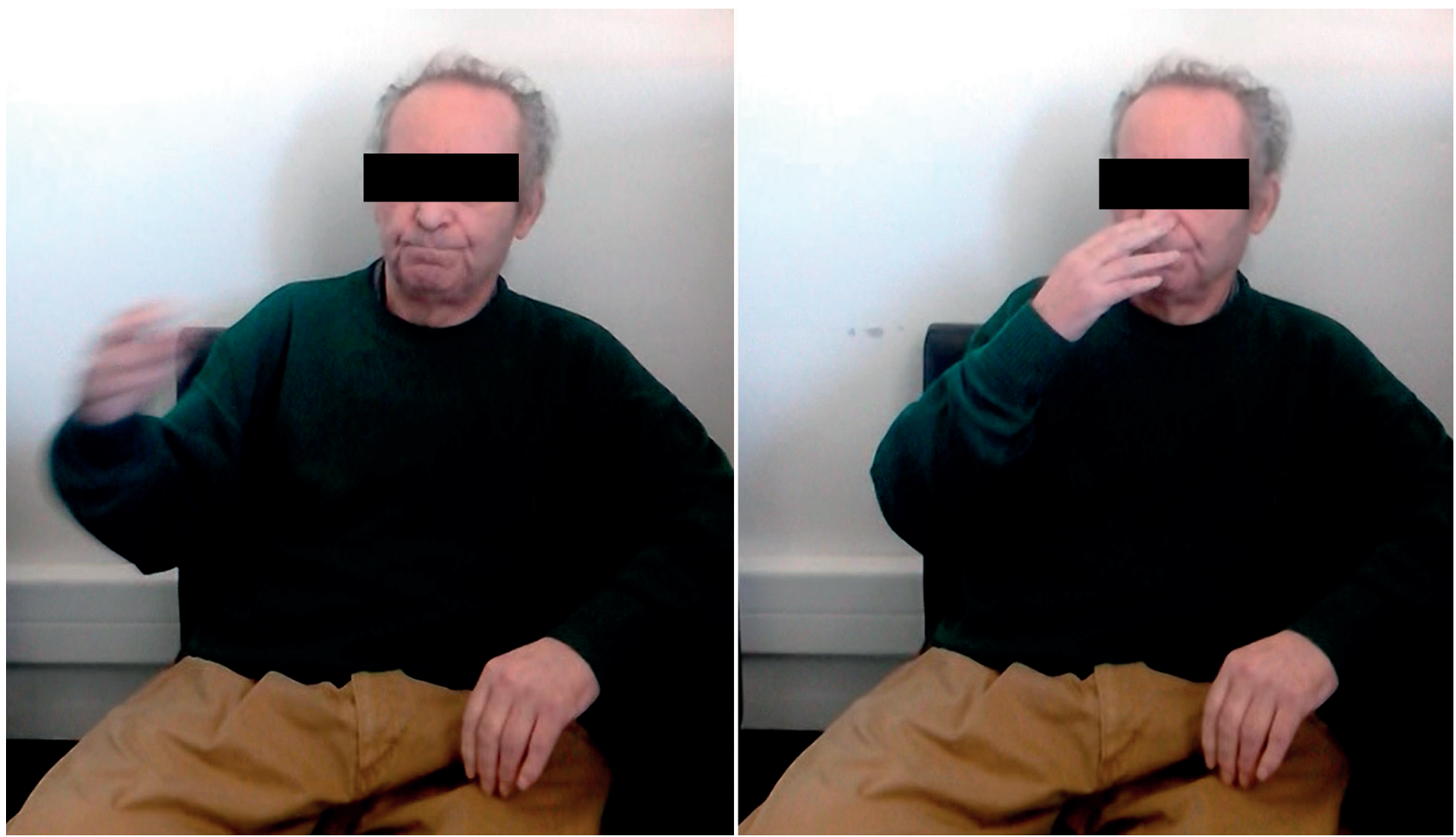

Figure 3 - Finger nose test ( 0 to 15 seconds); Tying his shoes (15 to 30 seconds); Visiting the inpatients unit after discharge ( 30 to 50 seconds); (see Video 3: https://www.actamedicaportuguesa.com/revista/index.php/amp/article/view/13029/Video_03.mp4)

ficult since several non-psychiatric conditions may present with similar features, and the clinical picture can easily be misinterpreted as a reflection of other primary psychiatric conditions. ${ }^{1}$ In the case described here, the patient presented with unusually severe major and minor manifestations of NMS, requiring continued invasive ventilation in the ICU due to ineffective cough reflex and accumulation of respiratory secretions. However, the existence of a previous infectious condition and the persistence of symptoms several weeks after the interruption of antipsychotic medication masked and delayed the diagnosis. In all suspected NMS cases, a careful review of medication is mandatory, and all dopamine-receptor antagonists should be immediately discontinued. Patients should be admitted to an ICU and supportive measures should be started. ${ }^{1}$ If an insufficient response is obtained, other measures should be considered, namely bromocriptine, dantrolene ${ }^{3}$ benzodiazepines $^{4}$ and/ or ECT. ${ }^{5}$ ECT may be used as first-line treatment, particularly when the condition is considered to be potentially lifethreatening. ${ }^{9}$ It is a low-risk intervention that prompts significant clinical improvement within a short time-interval, with the additional advantage of allowing treatment of catatonia due to other causes, namely catatonia that is secondary to another medical condition or to a mental disorder. Indeed, ECT seems to be effective in all forms of catatonia, which is particularly useful when the underlying cause is unknown. ${ }^{10}$

We previously reported the case of a 44-year-old woman with no relevant psychiatric history that was admitted due to metabolic encephalopathy secondary to acute renal failure and developed severe NMS after the administration of antipsychotics. The patient improved after interrup- tion of antipsychotics, followed by ECT and administration of a dopamine-receptor agonist. ${ }^{11}$ Here, ECT also resulted in significant improvement, with additional gains after introduction of bromocriptine, further supporting the diagnosis of NMS, rather than catatonia due to a mental disorder or medical condition. ${ }^{12}$ In both cases, diagnosis was delayed mainly because the clinical manifestations of NMS were recurrently attributed to other, previously diagnosed, systemic conditions. This unusually severe case thus illustrates the need for a high level of suspicion for NMS in critically ill patients with malignant catatonic syndromes, allowing for an early diagnosis and potentially life-saving treatment.

\section{ACKNOWLEDGEMENTS}

We thank Ana Velosa and all remaining clinical staff from Centro Hospitalar de Lisboa Ocidental that were involved in the care of this patient, namely the Intensive Care Unit and Neurology Department, as well as the Electroconvulsive Therapy Unit.

\section{PROTECTION OF HUMANS AND ANIMALS}

The authors declare that the procedures were followed according to the regulations established by the Clinical Research and Ethics Committee and to the 2013 Helsinki Declaration of the World Medical Association.

\section{DATA CONFIDENTIALITY}

The authors declare having followed the protocols in use at their working center regarding patients' data publication. 


\section{PATIENT AND FAMILY CONSENT}

Obtained.

\section{CONFLICTS OF INTERESTS}

Oliveira-Maia is recipient of a grant from Schuhfried $\mathrm{GmBH}$ for norming and validation of cognitive tests, national coordinator for Portugal of a Non-interventional Study (EDMS-ERI-143085581, 4.0) to characterize a TreatmentResistant Depression Cohort in Europe, sponsored by Janssen-Cilag Ltd., and national coordinator for Portugal

\section{REFERENCES}

1. Oruch R, Pryme IF, Engelsen BA, Lund A. Neuroleptic malignant syndrome: an easily overlooked neurologic emergency. Neuropsychiatr Dis Treat. 2017;13:161-75.

2. Tural U, Onder E. Clinical and pharmacologic risk factors for neuroleptic malignant syndrome and their association with death. Psychiatry Clin Neurosci. 2010;64:79-87.

3. Rosenberg MR, Green M. Neuroleptic malignant syndrome. Review of response to therapy. Arch Intern Med. 1989;149:1927-31.

4. Sadock B, Sadock V. Kaplan and Sadock's synopsis of Psychiatry: behavioral sciences/clinical psychiatry. $10^{\text {th }}$ ed. Philadelphia: Lippincott Williams \& Wilkins; 2011

5. Trollor JN, Sachdev PS. Electroconvulsive treatment of neuroleptic malignant syndrome: a review and report of cases. Aust N Z J Psychiatry. 1999;33:650-9.

6. Berman BD. Neuroleptic malignant syndrome. Neurohospitalist. 2011;1:41-7.

7. Adnet P, Lestavel P, Krivosic-Horber R. Neuroleptic malignant syndrome. of a trial of psilocybin therapy for treatment-resistant depression, sponsored by Compass Pathways, Ltd (EudraCT number 2017-003288-36), all outside of the submitted work. All remaining authors have declared that they have no relationships relevant to the contents of this paper to disclose.

\section{FUNDING SOURCES}

This research did not receive any specific grant from funding agencies in the public, commercial, or not-for-profit sectors.

BJA Br J Anaesth. 2000;85:129-35

8. Levenson JL. Neuroleptic malignant syndrome. Am J Psychiatry. 1985;142:1137-45.

9. nice.org.uk. London: National Institute for Health and Care Excellence, Guidance on the use of electroconvulsive therapy | Guidelines NICE. 2003-04. Actualizada em 2009-10. [consultado 2018 jul 24]. Disponível em: https://www.nice.org.uk/guidance/ta59/chapter/1-Guidance.

10. Luchini F, Medda P, Mariani MG, Mauri M, Toni C, Perugi G. Electroconvulsive therapy in catatonic patients: Efficacy and predictors of response. World J Psychiatry. 2015;5:182-192. doi:10.5498/wjp. v5.i2.182

11. Velosa A, Neves A, Barahona-Corrêa JB, Oliveira-Maia AJ. Neuroleptic malignant syndrome: a concealed diagnosis with multitreatment approach. BMJ Case Rep. 2019;12:e225840.

12. American Psychiatric Association. Diagnostic and statistical manual of mental disorders. $5^{\text {th }}$ ed. Arlington: American Psychiatric Publishing; 2013. 